\title{
Aksom H., Chornyi A. \\ RESOLVING EPISTEMOLOGICAL ISSUES IN THEORETICAL AND METHODOLOGICAL APPARATUS OF INSTITUTIONAL THEORIES OF ORGANIZATIONS
}

\begin{abstract}
Дослідники нової інституційної соціологї зосереджені на розгляді мотивів та раціональності постійної зміни вже побудованих історично та культурно інституційних середовищ. На сьогоднішній день найбільш перспективною та розвиненою теорією є теорія управлінських мод, яка передбачає, що інтереси та погляди окремих індивідів та колективів сочіально сконструйовані та сформовані під дією інституційних впливів. Відповідно, результатом цих переконань, спричинених інституційними наслідками, є не що інше, як поширення та прийняття адміністративних інновацій. Незважаючи на феноменологічні аргументи нової інституційної соціологї, що розглядає інституційний характер індивідуальних переконань, припущень та розумінь, дослідження з fashion management (управлінських мод) прямо суперечить іншим основним інституціональним твердженням про стабільність, інериію та стійкість до нових ідей та практик в інституиійних умовах. Тому об'єктом дослідження є сутність теорї управлінських мод з точки зору визначення ї онтологічних та епістомологічних ознак.

Унаслідок використання наукових методів логічного узагальнення та морфологічного аналізу в роботі стверджується, що одинищею аналізу мають виступати не макрорівневі процеси гомогенізації чи диверсифікацї організаційних середовищ, а мікропроцеси зміни технічних значень та характеристик адміністративних та організаційних практик. Так само, акцент досліджень має бути не на траєкторіях і особливостях поширення організаційних інновацій та практик, а на закономірностях їх інтерпретацї та осмислення індивідами та організаціями. Продемонстровано, як поєднання окремих аспектів теоретичного апарату Скандинавського інституціоналізму і теорії управлінських мод дозволяють досягти цієі мети та одночасно уникнути онтологічних розбіжностей.

Теоретичні ідеї, запропоновані в роботі, дозволяють уникнути типових недоліків в емпіричних дослідженнях, такі як неточність в інтерпретащї інституційних ефектів та помилкове трактування останніх як економічних та технічних факторів.
\end{abstract}

Ключові слова: теорія моди менеджмента, соціальні конструкти, інституціональна соціологія, інституиіональні ефекти.

\section{Introduction}

It is now widely recognized that institutional theory constitutes the dominant perspective on organizational behavior and structure [1-4]. Being developed as alternative to economic perspectives that viewed organizations as rational systems that pursue their goals in most efficient ways, over time new institutionalism acquired a status of the main theory of organizations. Institutional theory is well equipped to explain organizational actions and behaviors as acts of conformity under institutional pressures that push organizations to adopt similar structures and follows the same norms, rules and beliefs. At the same time, institutional arguments appeared to be unable to explain how change inside mature fields occur and how actors may recognize their needs and interests if latest are institutionally defined [5-9].

Management fashion theory has been developed partly in order to address this issue and explain change on the macro-level. Despite its fit to phenomenological arguments put forward by strong constructionist version of new institutional sociology regarding the institutional nature of individuals' beliefs, assumptions and understandings, management fashion literature seems directly contradicting another core institutional statement about stability, inertia and resistance towards novel ideas and practices in institutionalized settings. This paper attempts to clarify and resolve these two streams of literature by attending social construction perspective and revisiting its central tenets.

\section{The object of research and its technological audit}

The object of research is the essentiality of fashion management theory taking into account its ontological and epistemological characteristics. One of the most problematic areas is understanding the way institutions and fashions can be conceptualized upon the same mechanisms of emergence, reproduction and development.

Despite the multiplicity of explanations, it is argued in this paper that management fashion theory, although not formerly designed for change explanations, captures the essence of agency vs. structure quarrel better then special institutional change theories. Fashion theory concerned with trends and discourse in management knowledge markets which results in swings in popularity [10-14].

This most appropriately equipped theory of institutional mechanisms of management concepts adoption directly 
contradict intuitional theory and its core statements regarding stability and inertia across organizational fields. Fashion studies have gone a long way towards explaining relative transience in many organizational techniques, but struggle to explain why and some exhibit relative permanence. On the flipside, institutional studies have gone a long way in explaining relative persistence in many organizational techniques, but struggle to explain relative transience in institutions [15-17].

\section{The aim and objectives of research}

The aim of research is theoretization and enhance understanding the way institutions and fashions can be conceptualized upon the same mechanisms of emergence, reproduction and development.

In order to accomplish this task, the following sub questions need to be addressed:

1. To show, how to redirect empirical research from macro level studies of diffusion towards the micro level grounded in phenomenological reasoning.

2. To show, how each theory can be adapted to the socially constructed nature of institutional reality and how methodological tools can be modified in order to enable researchers to study this reality.

\section{Research of existing solutions of the problem}

The foundational argument of institutional theory is «that organizations exist in social contexts in which the rules of appropriate behavior are defined, not by economic rationality, but rather by prevailing myths of appropriate conduct that become so cognitively embedded that they influence managerial assumptions of efficiency and rationality [18]. Institutionalists turn attention away from internal organizational interests and pragmatic economic motivation towards organizational environments, viewing organizations not as technical but social systems which depend not on market forces but on institutional environments [19-22]. Further developments in institutional theory, inspired by micro theories like phenomenology and ethnomethodology [23, 24] allows looking «beyond market forces and the regulated industry but focuses instead on cultural factors, actions by states or professions, and how institutions shape markets or politics» [25-27]. The core idea behind the theories of institutional change, creation, modification and deinstitutionalization of institutions, therefore, remains that the very notions of interest, rationality and strategic behavior are socially constructed definitions elaborated through meaningful interaction [21, 23, 25, 28, 29]. Emerging as a chain of subjective judgments and opinions, over time certain elements and structures gain a taken-forgranted image, establishing itself as an objective reality, obtaining a rule-like status [30]. Apart from sanctions or pragmatic interests in symbolic conformity, rationalized structures mean that actors believe in its objectivity because other does the same [22]. These phenomenological arguments were incorporated more explicitly in experimental study where author adopted organization level analysis and, therefore, unpacked microfoundations of institutions. In research, institutionalization has been clearly conceptualized as a process by which «individual actors transmit what is socially defined as real and, at the same time, at any point in the process the meaning of an act can be defined as more or less a taken-for-granted part of this social reality. Institutionalized acts, then, must be perceived as both objective and exterior. Acts are objective when they are potentially repeatable by other actors without changing the common understanding of the act, while acts are exterior when subjective understanding of acts is reconstructed as intersubjective under-standing so that the acts are seen as part of the external world» [30].

As such, these «shared understandings result in certain organizations having to perform certain activities regardless of their rationale because of the taken-for-granted nature of those understandings» [31]. Organizations in highly institutionalized environments tend to dramatically reflect taken-for-granted elements in their formal structures in order to depict themselves as legitimate members of their social and cultural order. This phenomenon was used to be explained by the acceptance of dominating scripts and logics as the only obvious and natural way to conduct an activity [32] or by actors conformity to what is perceived in a given context as rational and appropriate. The latest statement appears to be interpreted differently in institutional literature. While more phenomenological argument states it that actors do believe in dominant institutional order and perceive it as the most appropriate and efficient means to desired ends [23, 33], other scholars undertake strategic perspective on agency vs. structure debate, leaving the space for conscious, pragmatic and purposive action. Adopting legitimate elements from environments doesn't mean pragmatism and strategic management of legitimacy but the minimal cognitive efforts in response to provided institutional templates. In contrast according to strategic view, actors can manipulate their environments, pretending to conform, while decoupling symbolically adopted elements from their technical day-to-day activities. In other cases, actors not only become aware of institutional constraints but actively engage in its change and deinstitutionalization in favor of more attractive alternatives. Such strategic view on agency and interest in institutional theory distorts its core assumptions, in particular the social constructed nature of institutional effects. As it was noted in [34], «it is important to keep in mind that the objectivity of the institutional world is a humanly produced, constructed objectivity. Before being «objectivated» (i. e. experienced as an objective reality) by human beings, institutions are produced by them. Human beings tend to believe that institutions have always been there because most often those who are constrained by institutions, and those who initially created these institutions, are not the same».

The key point here is that conformity is an unconscious and unintentional process since when facing rational myths individuals and organizations are unlikely to recognize their socially constructed nature and distinguish between shared beliefs and technical reality [35-37]. Conformity to institutional norms and rules stems not from the fear of sanctions and/or interest in gaining legitimacy and improve social position [30, 20]. Again, adopting institutional element or becoming infused with institutional value is largely unconscious and free from any cognitive efforts and decisionmaking process [23]. It is an acceptance that becomes possible because institutional understandings become so take-for-granted that actors perceive them as reality that needs to be accounted any way. Institutionalization occurs because certain combination of actions become so repetitive 
and stable that field members can save time and cognitive efforts on negotiations, analysis, doubts, decision making and strategizing. Institutionalized structures and patterns of actions bring stability and predictability - resources organizations value most [19, 38, 39].

All above mentioned features of institutions can be reduced to the notion of rational myths $[40,41]$. They are either widely prevailed or marginal practices or structures that have at least one common feature - they hold the notion about rationality and economic appropriateness. In the material structure it is a symbolic content that rationalize certain logic and course of actions [42], explaining why this structure is the optimal solution that leads to most efficient ends. When being faced with rational myth and considering its adoption actors do engage in decisionmaking process but base it on institutional value and shared meanings around the concept, accepting some sort of institutional value instead of former technical reality.

The notion of management fashion seems to fit these features best. In [10] defined as «relatively transitory collective beliefs...», the phenomenological roots are perfectly captured in the following conceptualization: «management fashion setting as the process by which management fashion setters continuously redefine both theirs and fashion followers' collective beliefs about which management techniques lead rational management progress». Although some reviewers claim fashion theory to be loosely coupled with institutional arguments [43], yet this definition reflects a socially constructed nature of managers' preferences, interests and understandings thus theorizing about both micro and macro levels of analysis [28, 44-46]. Additionally, fashion approach provides an answer to the question why some fashions come and go relatively fast while others stay and over time become institutions. That is, as transferable and reproducible set of belief systems, fashions have a potential to become institutions. This is indicated in many instances when fashionable concepts enter and become inevitable part of the everyday practice [43].

As a theory of stability, inertia and conformity, new institutionalism appeared to be unable to explain how change occurs $[5,7]$. In their attempts to balance this overemphasized view on social and cultural constrains over field members, thus, to resolve the paradox of embedded agency, many scholars infused actors in their analysis with so strong social skills and strategic vision that these actors appeared no more embedded in and constructed by their institutional environments [29, 47]. Instead, actors became active institutional entrepreneurs in studies of institutional change and transformation and rational, purposive decision-makers in diffusion studies. Several research streams, however, designed more compatible explanatory frameworks where actors' interests and motives were considered in their institutional context. These are institutional logics perspective, Scandinavian institutionalism and management fashion literature.

\section{Methods of research}

There are special and basic scientific methods and techniques to achieve the objectives:

- logical generalization to identify trends of fashion management conducted researches;

- synthesis to generalize the individual elements into

a holistic system of Scandinavian institutionalism;
- morphological analysis - to combine different methods and trends of the study of fashion management.

In addressing to the aim of research a literature review is a main source of empirical data.

\section{Research results}

The foregoing discussion now reaches its central point - to theorize the compatibility of fashion theory and institutional arguments as well as to compare it with another theory from institutional branch - Scandinavian institutionalism.

Although both theories put main emphasis on other then actors' motivation and interpretation issues (trajectories of diffusion in general and heterogeneity in translation theory and origins and discourses around new practices in fashion literature in particular), they rightly depict cultural construction of understandings and assumptions about rationality, technical efficiency and legitimacy benefits and/or threats. Fashion and translation research programs make it meaningless to distinguish between social and economic accounts in adoption motivations as in both approaches behavior and understandings are shaped and restricted by wider institutional forces [19, 22, 28, 48, 49].

Scandinavian institutionalism paints the same process of adopting rational myths as classic institutional statements based on phenomenology of institutions. Through imitation, adopters seek to join fashionable templates and fashions from different institutional environments. In doing so, they interpret external elements in accordance to domestic institutional logic, accounting for those editing rules, constructed by home institutional forces. Thus, the norms of rationality and progress, prevailed in novel practice home field are likely to differ with those norms, beliefs and understandings of rationality constructed by recipients' context. As a result of these divergent assumptions about reality, rationality and technical efficiency, adopters use to arrive with their own original versions of former practice.

The same can be noticed in fashion literature. New management techniques and concepts emerge on a regular basis, replacing existing, outdated solutions that contain obsolete beliefs about rationality and progress [10]. Fashionsetting communities regularly redefine what is rational, and how to succeed under these norms of rationality and by which means. By accepting these transitory collective beliefs about what is at the forefront of the management progress [10], adopters naturally perceive fashions as means to optimal ends, therefore, there is no point to assume legitimacy concerns - motivation for adoption is driven by technical efficiency interests, rational economic behavior. Management fashion theory, thus, explicitly claim the institutional construction of individual and organizational behavior and economic interests. Translation theory then describe how these global, external rational myths, validated as get additionally revisited and reconstructed in accordance with local institutional context which, in turn, clarifies certain points about rationality and applying of most efficient means to important ends [10].

Revisited from social constructionist perspective, translation and fashion theories offer rather better understating of value infusion and shifts in meanings than prevailing institutional research strategies. Both approaches depart from simple economic-legitimacy motives dichotomy and examine instead, how formerly interest-driven actors interpret 
new practices and share existing institutional meanings or attach local shared understandings to global ideas.

Rational myths constitute a central theoretical notion in [19] on institutional theory and fashion perspective on practices diffusion and adoption offers well suited research tools for studying motivation for adoption and not only supply side, trajectories and patterns of fashion waves. Therefore, the most detailed extension on institutional myths was offered in management fashion literature. In particular, figuring out what drives managers to adopt new administrative models, concepts and techniques relatively uncritically, thus, accounting for the number and quality of adopters then for innovations per se [11]. This conceptualization of norms of rationality and progress is a direct reference to strong social constructionist perspective on institutional effects: in any institutional environment there are specific assumptions, beliefs and understandings of rationality and efficiency which managers acknowledge, «understand» and do their best to meet this institutionally constructed expectations. It's not enough to assume that a search for modernity is the major imperative for practice adoption. Instead, adopters look for rationality and progress when adopting novel practices. Here, again, managers either believe in these criteria and strive for fit with the norm of rationality provided by the dominant institutional logic or don't believe but conform to expectations in order to acquire legitimacy and get rewarded in financial or reputational terms [50].

Fashion literature echoes phenomenological sociology in the most important aspect, namely, in sharing the same view on the nature and mechanisms of social order reproduction [24]. As in [22] summarizes, «the truly fundamental beliefs for reproducing a social order are people's beliefs about others' behaviour and beliefs; the basic «myths» of society operate primarily by establishing beliefs about what others think and expectations about how others will behave». What can be considered as a pragmatic and purposeful adaptation of the management concept to personal needs and interests [13] institutional theory views as a conformity to local institutionally invented criteria of what is rational, logical and optimal [28, 48, 49]. Scholars explicitly stress the local legitimacy criteria which identifies what is rational and progressive in the following passage: «waves of interest in management techniques occur when national norms of both rationality and progress govern managerial behaviour» [10]. That is, an institutional logic dominating in any specific setting or context already defines this rationality and scientific paper distinguishes institutional logics and fields geographically. Similarly to former institutional studies, fashions arise and proliferate when their institutional rationalization articulate what is rational and progressive, drawing from past experiences and success stories and not from adopters' isolated interests. Like myths, fashions adoptions inhere «not in the fact that «individuals believe them, but in the fact that they «know» everyone else does...» [40].

In locating fashion and translation theory within institutional analysis it is important to emphasis not macro institutional effect but to attend microfoundations. Instead of focusing on homogeneity/heterogeneity and permanence/transience nature of fashions and institutions it is more fruitful to focus once again on actors' sense making. The main point of both perspectives must be that actors adopt new ideas because of the institutional in- fluences and cultural and historical construction of norms of rationality. Instead of focusing on maintenance and stability of institutional myths, researchers may ask why field members are sensitive to new myths and why institutional content is more important than technical foundations. Shifting the level of analysis from macro to micro perspective allows uncovering meanings actors attach to structures and elements. Furthermore, it becomes possible to observe and understand how their interpretations are influenced and distorted by institutional effects, how shared social reality appears to be more important in decision making then critical analysis isolated from any external influences. Therefore, the main point in all branches of institutional research program might be not the macro processes of homogenization or issues of transience or permanence but the process of social construction of reality, the way «individuals come to accept a shared definition of social reality» [21] regardless of the extend of myths' prevalence and taken-for-grantedness.

Although, as this paper argued, management fashion perspective offers one of the well-suited tools for researching adopters' motivations and, thus, the value infusion, still scholars pay little attention to the issue of institutional content and its interpretation by field members. The focus of most appropriate frameworks is on answering different research questions that loosely coupled with motivation and interpretation. Institutional logics perspective aims answering how actors perceive and resolve institutional complexity, translation theory deals with decoupling and homogeneity stereotypes in institutional studies and management fashion theory responds to bell-shaped swings in the popularity of management concepts. The present study put forward arguments that it is not homogeneity or symbolic pragmatic conformity should be the main units of analysis but the meanings that individuals attach to technical structures and elements; not the trajectories and waves of popularity of ideas and structures but the way subjective judgments and interpretations acquire objective status and eclipse former technical foundations. Detailed case studies favored among Scandinavian institutionalists when equipped with fashion theory definition of new ideas as collective beliefs that a «management technique is at the forefront of management progress» will help to trace the process when these ideas become «infused with value beyond the technical requirements at hand» [51].

\section{SWOT analysis of research results}

Strengths. We managed to explain motives and reasons why communities and adopters always perceive new management and leadership theories like those that are rational and ready for practical application in their local context.

Weaknesses. The weak side of the research is the lack of quantitative data on the emergence and acceptance of new management and leadership theories by the scientific community.

Opportunities. To expand the research with interviews of Ukrainian management and leadership theorists.

Threats. Fundamental principles, which are basic of the theories discussed in the article, may not be complete. Consequently, we could overlook certain aspects of the problem of perceiving new management and leadership theories. 


\section{Conclusions}

1. It is shown that neither former institutional theory nor its modern alternatives should focus exclusively on the trajectory and logic of diffusion of institutional templates. Instead, it is argued that in the middle of the empirical and theoretical focus need to be individuals' interpretations of institutional prescriptions and demands. This redirection also allows linking macro and micro levels of analysis and making institutional perspectives working both within qualitative and quantitative modes of analysis.

2. The conducted research turns the attention towards the ontological foundation of each theory and speculates how each can be adapted to the socially constructed nature of institutional reality and how methodological tools can be modified in order to enable researchers to study this reality. Specifically, it is offered to reduce the conceptualization of institutions and organizations back from agency-centered depiction and strategic-perspective towards over-socialized picture with adequately addresses the prevalence of macrolevel forces over micro-level individuals.

\section{References}

1. Mizruchi M. S., Fein L. C. The Social Construction of Organizational Knowledge: A Study of the Uses of Coercive, Mimetic, and Normative Isomorphism // Administrative Science Quarterly. 1999. Vol. 44, No. 4. P. 653-683. doi: http:// doi.org/10.2307/2667051

2. Lounsbury M. Institutional rationality and practice variation: New directions in the institutional analysis of practice // Accounting, Organizations and Society. 2008. Vol. 33, No. 4-5. P. 349-361. doi: http://doi.org/10.1016/j.aos.2007.04.001

3. Modell S. Institutional research on performance measurement and management in the public sector accounting literature: a review and assessment // Financial Accountability \& Management. 2009. Vol. 25, No. 3. P. 277-303. doi: http://doi.org/ 10.1111/j.1468-0408.2009.00477.x

4. Scott W. R. Institutions and Organizations: Ideas and Interests. Thousand Oaks: Sage, 2008. 267 p.

5. Oliver C. Strategic responses to institutional processes // Academy of Management Review. 1991. Vol. 16, No. 1. P. 145-179. doi: http://doi.org/10.5465/amr.1991.4279002

6. Scott W. R. Unpacking institutional arguments // The new institutionalism in organizational analysis / ed. by Powell W., Dimaggio P. Chicago: University of Chicago Press, 1991. P. 164-182.

7. Holm P. The Dynamics of Institutionalization: Transformation Processes in Norwegian Fisheries // Administrative Science Quarterly. 1995. Vol. 40, No. 3. P. 398-442. doi: http:// doi.org/10.2307/2393791

8. Sherer P. D., Lee K. Institutional change in large law firms: a resource dependency and institutional perspective // Academy of Management Journal. 2002. Vol. 45, No. 1. P. 102-119 doi: http://doi.org/10.2307/3069287

9. Greenwood R., Hinings C. R., Suddaby R. Theorizing change: the role of professional associations in the transformation of institutionalized fields // Academy of Management Journal. 2002 Vol. 45, No. 1. P. 58-80. doi: http://doi.org/10.2307/3069285

10. Abrahamson E. Management fashion // Academy of Management Review. 1996. Vol. 21, No. 1. P. 254-285. doi: http:// doi.org/10.5465/amr.1996.9602161572

11. Kieser A. Rhetoric and Myth in Management Fashion // Organization. 1997. Vol. 4, No. 1. P. 49-74. doi: http://doi.org/ 10.1177/135050849741004

12. Clearing A Path Through The Management Fashion Jungle: Some Preliminary Trailblazing / Carson P. P. et al. // Academy of Management Journal. 2000. Vol. 43, No. 6. P. 1143-1158. doi: http://doi.org/10.5465/1556342

13. Benders J., Van Veen K. What's in a fashion? Interpretative viability and management fashions // Organization. 2001. Vol. 8, No. 1. P. 33-53. doi: https://doi.org/10.1177/135050840181003

14. Benders J., Nijholt J., Heusinkveld S. Using Print Media Indicators in Management Fashion Research // Quality \& Quantity.
2006. Vol. 41, No. 6. P. 815-829. doi: http://doi.org/10.1007/ s11135-006-9027-5

15. Madsen D. O., Stenheim T. Doing research on 'management fashions': methodological challenges and opportunities // Problems and Perspectives in Management. 2013. Vol. 11, No. 4. P. $68-76$

16. Madsen D., Slatten K. The Role of the Management Fashion Arena in the Cross-National Diffusion of Management Concepts: The Case of the Balanced Scorecard in the Scandinavian Countries // Administrative Sciences. 2013. Vol. 3, No. 3. P. 110-142. doi: http://doi.org/10.3390/admsci3030110

17. Abrahamson E., Chang S., Katic I. Institutional Transience and Fashion Persistence: Outlines of an Evolutionary Theory of Fashions and Institutions: proceedings. Montreal: EGOS, 2013.

18. Suddaby R. Can Institutional Theory Be Critical? // Journal of Management Inquiry. 2014. Vol. 24, No. 1. P. 93-95. doi: http://doi.org/10.1177/1056492614545304

19. Meyer J. W., Rowan B. Institutionalized Organizations: Formal Structure as Myth and Ceremony // American Journal of Sociology. 1977. Vol. 83, No. 2. P. 340-363. doi: http:// doi.org/10.1086/226550

20. Zucker L. Institutional Theories Of Organization // Annual Review of Sociology. 1987. Vol. 13, No. 1. P. 443-464. doi: http:// doi.org/10.1146/annurevsoc.13.1.443

21. Scott W. R. The Adolescence of Institutional Theory // Administrative Science Quarterly. 1987. Vol. 32, No. 4. P. 493-511. doi: http://doi.org/10.2307/2392880

22. Jepperson R. The development and application of sociological institutionalism // Contemporary sociological theory: New directions / ed. by Berger P., Zelditch M. Lanham: Rowman \& Littlefield, 2002. 232 p.

23. Meyer J. W. Reflections on institutional theories of organizations // Handbook of Organizational Institutionalism / ed. by Greenwood R. et al. Thousand Oaks: Sage Publications, 2008. P. 790-811.

24. Meyer J. W. World Society, Institutional Theories, and the Actor // Annual Review of Sociology. 2010. Vol. 36, No. 1. P. 1-20. doi: http://doi.org/10.1146/annurev.soc.012809.102506

25. Schneiberg M., Bartley T. Regulating American Industries: Markets, Politics, and the Institutional Determinants of Fire Insurance Regulation // American Journal of Sociology. 2001 Vol. 107, No. 1. P. 101-146. doi: http://doi.org/10.1086/323574

26. Meyer J. W., Jepperson R. L. The «Actors» of Modern Society: The Cultural Construction of Social Agency // Sociological Theory. 2000. Vol. 18, No. 1. P. 100-120. doi: http://doi. org/10.1111/0735-2751.00090

27. Schneiberg M. Combining New Institutionalisms: Explaining Institutional Change in American Property Insurance // Sociological Forum. 2005. Vol. 20, No. 1. P. 93-137. doi: http:// doi.org/10.1007/s11206-005-1899-y

28. Friedland R., Alford R. R. Bringing society back in: Symbols, practices, and institutional contradictions. The new institutionalism in organizational analysis / ed. by Powell W. W., Dimaggio P. J. Chicago: University of Chicago Press, 1991. P. $232-267$.

29. Suddaby R. Challenges for Institutional Theory // Journal of Management Inquiry. 2010. Vol. 19, No. 1. P. 14-20. doi: http:// doi.org/10.1177/1056492609347564

30. Zucker L. G. The Role of Institutionalization in Cultural Persistence // American Sociological Review. 1977. Vol. 42, No. 5. P. 726-743. doi: http://doi.org/10.2307/2094862

31. Taking social construction seriously: Extending the discursive approach in institutional theory / Phillips N., Malhotra N.; ed. by Greenwood R. et al. // The Sage Handbook of Organizational Institutionalism. London: Sage, 2008. P. 702-720.

32. Oliver C. The Antecedents of Deinstitutionalization // Organization Studies. 1992. Vol. 13, No. 4. P. 563-588. doi: http:// doi.org/10.1177/017084069201300403

33. Drori G. S., Meyer J. W., Hwang H. Global organization Rationalization and actorhood as dominant scripts // Research in the Sociology of Organizations. 2009. Vol. 27. P. 17-43. doi: https://doi.org/10.1108/s0733-558x(2009)0000027003

34. Berger P. L., Luckmann T. The Social Construction of Reality. New York: Doubleday Anchor, 1967. 247 p.

35. Zbaracki M. J. The Rhetoric and Reality of Total Quality Management // Administrative Science Quarterly. 1998. Vol. 43, No. 3. P. 602-636. doi: http://doi.org/10.2307/2393677 
36. Zilber T. B. Institutionalization as an interplay between actions, meanings, and actors: the case of a rape crisis center in Israel // Academy of Management Journal. 2002. Vol. 45, No. 1. P. 234-254. doi: http://doi.org/10.2307/3069294

37. Aksom H. Disentangling social constructions from technical realities: a case of Beyond Budgeting in Ukraine: proceedings. Vilnius, 2016. P. 27-28.

38. Coalface institutionalism // The Sage handbook of organizational institutionalism / Barley S. R.; ed. by Greenwood R. et al. London: SAGE Publications, 2008. P. 338-364. doi: http:// doi.org/10.4135/9781446280669.n14

39. Hannan M. T., Freeman J. Structural Inertia and Organizational Change // American Sociological Review. 1984. Vol. 49, No. 2. P. 149-164. doi: http://doi.org/10.2307/2095567

40. Meyer J. W. The Effects of Education as an Institution // American Journal of Sociology. 1977. Vol. 83, No. 1. P. 55-77. doi: http://doi.org/10.1086/226506

41. Hallett T. The Myth Incarnate: Recoupling Processes, Turmoil, and Inhabited Institutions in an Urban Elementary School // American Sociological Review. 2010. Vol. 75, No. 1. P. 52-74. doi: http://doi.org/10.1177/0003122409357044

42. Strang D., Meyer J. W. Institutional conditions for diffusion // Theory and Society. 1993. Vol. 22, No. 4. P. 487-511. doi: http:// doi.org/10.1007/bf00993595

43. Perkmann M., Spicer A. How are management fashions institutionalized? The role of institutional work // Human Relations. 2008. Vol. 61, No. 6. P. 811-844. doi: http://doi.org/ $10.1177 / 0018726708092406$

44. Friedland R. Institution, practice, and ontology: Toward a religious sociology // Research in the Sociology of Organizations. 2009. Vol. 27. P. 45-83. doi: http://doi.org/10.1108/ s0733-558x(2009)0000027004

45. Lounsbury M., Boxenbaum E. Institutional Logics in Action // Research in the Sociology of Organizations. 2013. Vol. 39 P. 3-22. doi: http://doi.org/10.1108/s0733-558x(2013)0039a004
46. Zilber T. B. Institutional Logics and Institutional Work: Should They Be Agreed? // Research in the Sociology of Organizations. 2013. Vol. 39. P. 77-96. doi: http://doi.org/10.1108/ s0733-558x(2013)0039a007

47. Organizations and their institutional environments - Bringing meaning, values, and culture back in: Introduction to the special research forum / Suddaby R. et al. // Academy of Management Journal. 2010. Vol. 53, No. 6. P. 1234-1240. doi: http:// doi.org/10.5465/amj.2010.57317486

48. Dobbin F. Forging industrial policy: The United States, Britain, and France in the railway age: monograph. Cambridge University Press, 1994. 262 p. doi: http://doi.org/10.1017/ cbo9781139174183

49. Bartley T., Schneiberg M. Rationality and Institutional Contingency: The Varying Politics of Economic Regulation in the Fire Insurance Industry // Sociological Perspectives. 2002. Vol. 45 No. 1. P. 47-79. doi: http://doi.org/10.1525/sop.2002.45.1.47

50. Staw B. M., Epstein L. D. What Bandwagons Bring: Effects of Popular Management Techniques on Corporate Performance, Reputation, and CEO Pay // Administrative Science Quarterly. 2000. Vol. 45, No. 3. P. 523-556. doi: http://doi.org/ $10.2307 / 2667108$

51. Selznick P. Leadership in administration. Evanston: Row, Peterson, 1957. 162 p.

Aksom Herman, Postgraduate Student, Department of Innovation and Investment Management, Taras Shevchenko National University of Kyiv, Ukraine, e-mail: axyomg@ukr.net, ORCID: https://orcid.org/ 0000-0002-0566-2965

Chornyi Anton, Postgraduate Student, Department of Innovation and Investment Management, Taras Shevchenko National University of Kyiv, Ukraine, e-mail: chornyiav@gmail.com, ORCID: https:// orcid.org/0000-0001-9857-2151 